\title{
Sistem Informasi Geografis Penentuan Rute Terpendek Lokasi Villa Menggunakan Algoritma Floyd Warshall
}

\author{
Hendro Wijayanto' ${ }^{1)}$; Didik Nugroho'); Beni Aryo Santoso ${ }^{3)}$ \\ ${ }_{1,2,3)}$ Program Studi Teknik Informatika, STMIK Sinar Nusantara \\ ${ }^{1)}$ hendro@sinus.ac.id ; ${ }^{2)}$ didik@sinus.ac.id; ${ }^{3)}$ beni.aryo95@gmail.com
}

\begin{abstract}
Tawangmangu district has many types of villa that can be welcome for the local people and the community itself. Information about the location of villa needed by tourists and also the general public is the route information to the villa in Tawangmangu district. The aim of the research is to apply Floyd Warshall algorithm in finding the shortest route for villa in Tawangmangu district which has 150 and about 30 in the Web interface with the help of Google Maps API. The closest villa location to the Grojokan sewu tourist is the Indra Sari villa with 245 meters of yield. For the comparisons, Google Maps got $80 \%$ result of the 30 different test paths and due diligence with respondents showed a feasibility rate of $88,75 \%$ indicating that the application is well-deserved by the user. Floyd Warshall algorithm is applied because the principle of the algorithm Floyd Warshall is the principle of optimality. The result is an application that can show the shortest route, along with from the starting location to the destination location of the villa.
\end{abstract}

Keywords: Geographic Information Systems, Floyd Warshall, Shortest Route

\section{PENDAHULUAN}

Kecamatan Tawangmangu adalah salah satu kecamatan penuh dinamika yang mempunyai berbagai tempat wisata dan berbagai macam penginapan. Memiliki potensi besar untuk mendatangkan banyak wisatawan baik lokal maupun mancanegara. Kecamatan Tawangmangu mempunyai sekitar 150 Villa yang tersebar dibeberapa kelurahan dengan rincian seperti Tabel 1 berikut ini.

Tabel 1. Sebaran Villa

\begin{tabular}{|l|c|c|}
\hline \multicolumn{1}{|c|}{ Kelurahan } & $\begin{array}{c}\text { Villa } \\
\text { Pribadi }\end{array}$ & $\begin{array}{c}\text { Villa } \\
\text { Disewakan }\end{array}$ \\
\hline Kalisoro & 6 & 4 \\
\hline Blumbang & 5 & 5 \\
\hline Tawangmangu & 4 & 5 \\
\hline
\end{tabular}

Dalam membangun tempat wisata dan penginapan, banyak hal yang perlu diperhatikan, diantaranya mengenai sektor transportasi. Transportasi merupakan sarana vital yang menunjang perjalanan suatu tempat wisata dan penginapan. Letak geografis Kecamatan Tawangmangu yang memiliki jalan perkampungan dengan lebar jalan relatif sempit membuat beberapa kendaraan kesulitan menuju destinasi tujuan wisata atau penginapan. Sehingga untuk menempuhnya harus memutar atau memilih jalan yang lain.

Di sisi lain, pemanfaatan fasilitas Global Positioning System (GPS) belum terlalu efektif untuk memberikan petunjuk arah. Terkadang hasil dari GPS tidak sesuai dengan kenyataan. Misalnya jalan yang ditunjukkan oleh sistem GPS hanya dapat dilalui oleh kendaraan kecil atau jalan setapak.

Dari permasalahan tersebut dapat ditarik masalah bagaimana membuat teknologi yang membantu pengguna dalam menemukan lokasi Villa dan statusnya. Diantaranya menggunakan teknologi Sistem Informasi Geografi. Geographic Information System atau dikenal juga dengan GIS/SIG (Sistem Informasi Geografis) adalah sistem berbasis komputer untuk mengelola, menganalisis dan menyebarkan informasi geografis [1][2].

Google Maps yang sudah lumayan canggih tapi masih kurang dalam mengulas di wilayah Kecamatan Tawangmangu diantaranya kurangnya informasi villa yang di sewakan dan tidak disewakan / villa pribadi dan dalam SIG yang dibangun ini akan adanya informasi serta mengkategorikan villa disewakan dan tidak disewakan / villa pribadi tersebut nantinya akan ditanamkan algoritma yang berfungsi sebagai pencari rute optimum dari lokasi asal ke lokasi villa yang di tuju, dan algoritma yang digunakan adalah FloydWarshall.

Pemilihan algoritma tersebut dikarenakan algoritma ini merupakan bagian dari algoritma dinamik yang dapat mencari semua lintasan terpendek masing-masing antara tiap kemungkinan pasang tempat yang berbeda 
(All-pairs Shortest Path Problems) dan sangat efektif digunakan dalam menangani masalah rute optimum [3].

Dari masalah diatas inilah yang mendasari pembuatan aplikasi penentuan rute terpendek lokasi villa menggunakan algoritma Floyd Warshall berbasis Web GIS di Kecamatan Tawangmnagu, yang akan di tampilkan dalam sebuah web dengan bantuan interface dari Google Maps API. Perangkat lunak ini akan menampilkan berbagai villa yang ada dikecamatan Tawangmangu, dan menuntun user harus menginputkan lokasi awal (keberadaan) dan lokasi akhir (tujuannya). Rute optimum yang dimaksud adalah rute/jalan tercepat yang akan dilalui dengan kendaraan. Dengan terbentuknya aplikasi ini nanti diharapkan masyarakat pendatang dapat memangkas waktu tempuh dalam pemilihan villa, serta memperoleh informasi detail dari villa di Kecamatan Tawangmangu.

\section{TINJAUAN PUSTAKA}

Application Programming Interface atau API adalah sekumpulan perintah, fungsi, dan protokol yang dapat digunakan oleh programmer saat membangun perangkat lunak untuk sistem operasi tertentu. Menurut web Google Maps for Bussines, Google Maps API adalah kumpulan API yang memungkinkan pengguna menghamparkan data pada Google Maps yang disesuaikan. Pengguna dapat membuat aplikasi web dan seluler menarik dengan platform pemetaan canggih dari Google termasuk basis data citra satelit, pemandangan jalan, profil ketinggian, petunjuk arah mengemudi, peta dengan sentuhan gaya, demografi, analisis, dan tempat yang luas [4].

Google Maps merupakan SIG yang berbasis internet yang diberikan Google secara gratis, termasuk di dalamnya website Google Maps (http://maps.google.com), Google Ride Finder, Google Translate, dan peta yang dapat disisipkan pada website lain melalui Google Maps API. Saat ini Google Maps adalah layanan pemetaan berbasis web yang popular. User membuat aplikasi dengan menambahkan layanan Google Maps ke website yang dibuatnya. Google Maps API dapat ditambahkan ke sebuah website menggunakan JavaScript. API tersebut menyediakan banyak fasilitas dan utilitas untuk memanipulasi peta dan menambahkan konten ke peta melalui berbagai layanan, memungkinkan user untuk membuat aplikasi peta yang kuat pada sebuah website. Namun untuk dapat mengakses Google Maps, terlebih dahulu user harus melakukan pendaftaran API key dengan data pendaftaran berupa nama domain web yang kita bangun. Google Map API mengijinkan kepada pengguna untuk membangun aplikasi enterprise di dalam websitenya.

Graf merupakan struktur data yang paling umum. Jika struktur linear memungkinkan pendefinisian keterhubungan sikuensial antara entitas data, struktur data tree memungkinkan pendefinisian keterhubungan hirarkis, maka struktur graph memungkinkan pendefinisian keterhubungan tak terbatas antara entitas data. Graf sering digunakan dalam berbagai disiplin ilmu, seperti pengelolaan intertautan jaringan, memetakan jalan raya antarkota, memodelkan objek tiga dimensi, hingga pemetaan DNA pada manusia [5].

Dalam penelitian [6] telah dilakukan penelitian untuk menentukan rute terpendek ke obyek wisata populer di Kota Semarang. Floyd Warshall digunakan untuk menghitung jarak simpul antar titik obyek wisata. Adapun didalamnya belum menggunakan peta, sehingga rute hanya berdasarkan jarak tanpa menggambarkan titik dan jalur dalam bentuk interface peta.

Pemodelan Floyd-Warshall juga dapat digunakan untuk mencari titik terdekat dalam pencarian kendaraan di tempat parkir. Sehingga dapat mempersingkat waktu pencarian, mengoptimalkan daya tampung parkir, dan memudahkan pemilik kendaraan dalam menentukan blok mana harus dilewati untuk menemukan kendaraannya [7].

Algoritma Floyd Warshall diciptakan oleh R. Floyd pada tahun 1962. Algoritma Floyd Warshall adalah salah satu pemrograman dinamis, yaitu suatu metode yang melakukan pemecahan masalah dengan memandang solusi yang akan diperoleh sebagai suatu keputusan yang saling terkait. Artinya solusisolusi tersebut dibentuk dari solusi yang berasal dari tahap sebelumnya dan ada kemungkinan solusi lebih dari satu. Floyd Warshall merupakan algoritma untuk pencarian lintasan terpendek pada suatu graf berbobot (weighted graph). Algoritma ini dapat melakukan analisis dan penyelesaian kerumitan suatu proses [8]. 


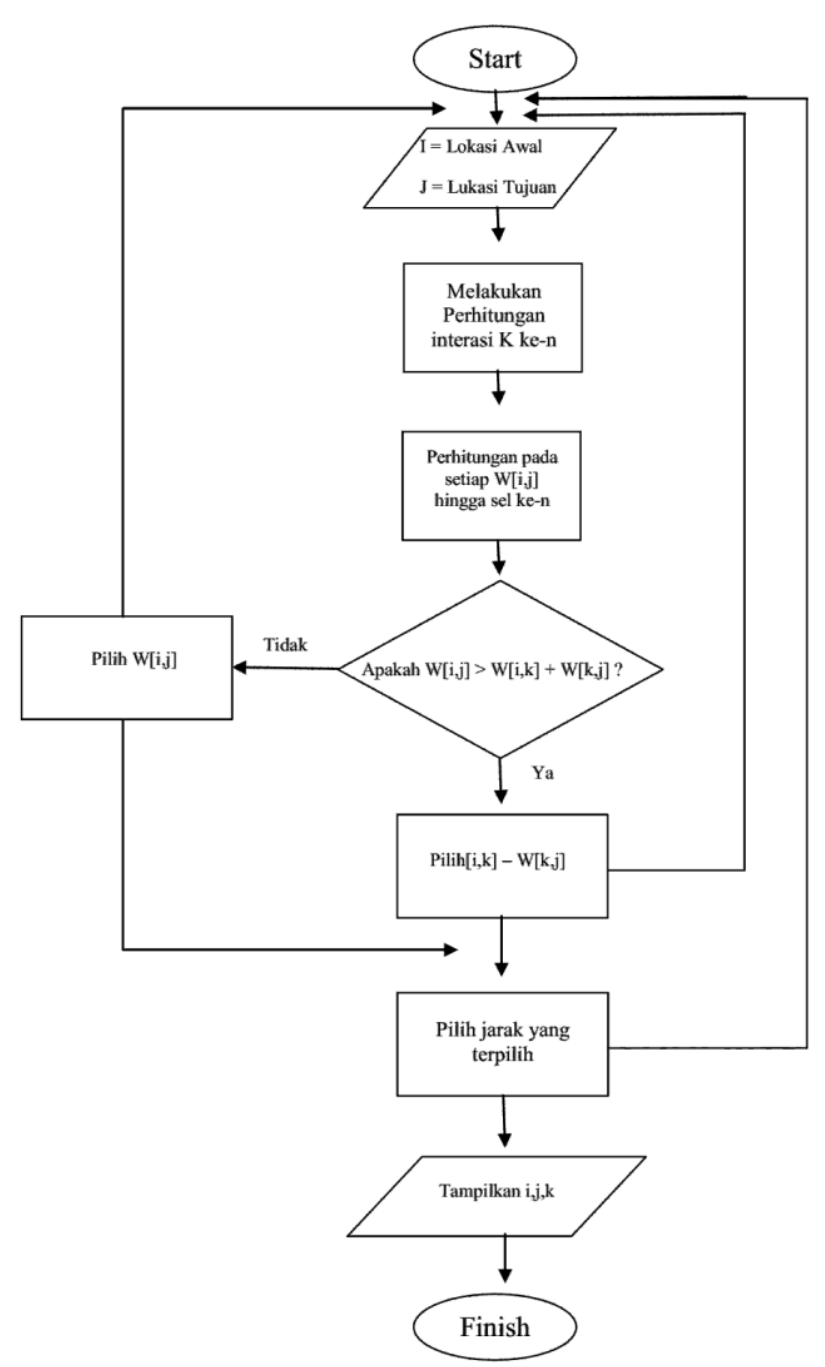

Gambar 1. Floyd Warshall

Alur Algoritma Floyd Washall berdasarkan gambar yaitu:

1. Yang pertama dilakukan adalah menginputkan lokasi awal dan lokasi tujuan sabagai data.

2. Pada iterasi 1, setiap sel matriks dilakukan pengecekan apakah antar dua titik lebih besar dari penjumlahan antar titik asal ke titik tujuan (titik tujuan = iterasi $\mathrm{k}-1$ ) dengan jarak titik asal (titik asal = iterasi $\mathrm{k}-10$ ke tujuan. Dengan kata lain $W[i, j]>W[i, k]+W[k, j]$.

3. Jika iya maka jarak yang digunakan adalah jarak antar dua titik diganti dengan penjumlahan antar titik asal ke (titik tujuan = iterasi $\mathrm{k}-1$ ) dengan jarak titik asal (titik a = iterai 1) ke titik tujuan $\mathrm{W}[\mathrm{i}, \mathrm{k}]+\mathrm{W}[\mathrm{k}, \mathrm{j}]$.

4. Jika tidak maka jarak yang digunakan yaitu dua titik W[i,j].

5. Proses iterasi dilakukan hingga iterasi terakhir (iterasi terakhir $=$ total titik atau node / k-n).

6. Hasil terakhir berupa jarak optimal dar setiap lokasi awal menuju lokasi tujuan.
Pengujian dilakukan menggunakan pengujian validitas dan pengujian kepuasan pengguna. Pengujian validitas dilakukan untuk mengukur seberapa perbedaan antara aplikasi yang telah dirancang dengan Google Maps. Sedangkan pengujian pengukuran kepuasan digunakan untuk melihat kepuasan pengguna aplikasi.

\section{METODE PENELITIAN}

\subsection{Pengumpulan Data}

1. Metode Interview (wawancara)

Metode interview ini dilakukan tanya jawab dengan staf umum dikecamatan Tawangmangu berkaitan tentang nama villa dan jumlah villa yang ada dikecamatan Tawangmangu.

2. Observasi

Penulis mengunjungi lokasi villa untuk mengambil 30 koordinat lokasi villa dan meninjau langsung lokasi villa.

3. Studi Literatur

Pada metode ini penulis mengumpulkan data mengenai pokok-pokok bahasan yang berkaitan dengan penyusunan laporan yaitu mempelajari beberapa karya ilmiah, artikel dan referensi-referensi yang berkaitan dengan algoritma Floyd warshall, Graf, dan lokasi villa di Kecamatan Tawangmangu yang dapat digunakan sebagai acuan dalam penulisan.

\subsection{Pengembangan Sistem}

1. Analisa Sistem

Hasil dari pencarian data secara primer diperoleh data lokasi villa, jarak, dan jalan, yang akan digunakan untuk membuat aplikasi penentuan rute terpendek. Persoalan mencari rute terpendek di dalam graf merupakan salah satu persoalan optimasi. Graf yang digunakan dalam pencarian rute terpendek adalah graf berbobot (weighted graph), yaitu graf yang setiap sisinya diberikan suatu nilai atau bobot

2. Perancangan Sistem

a. Diagram Konteks

Diagram ini menggambarkan sistem penentuan rute terpendek secara garis besar dalam memperlihatkan masukan proses dan keluaran dari sistem yang akan dirancang untuk lokasi villa dan menggunakan algoritma Floyd warshall di Kecamatan Tawangmangu. 
b. Hierarchy Input Proses Output HIPO digunakan untuk mempersiapkan penggambaran diagram alir data untuk menuju levellevel lebih bawah, dimana memiliki jenjang yaitu top level, level 0 ,dan level 1.

c. Desain Diagram Alir Data

Diperlukannya DFD (data flow diagram) yaitu suatu model logika data atau proses dibuat untuk menggambarkan darimana asal data dan kemana tujuan data yang keluar dari sistem, dimana data disimpan, proses apa yang menghasilkan data tersebut dan interaksi antara data yang tersimpan dan proses yang dikenakan pada data tersebut. Model fungsional ini berfungsi membantu memahami cara kerja sistem dan hubungan setiap proses dalam sistem secara terstruktur dan logis.

d. Perancangan Database

1. Entity Relationship Diagram (ERD)

ERD untuk menggambarkan hubungan satu tabel dan tabel lainnya. Sehingga dapat terlihat batasan-batasannya hubungan dari satu tabel yang dibuat. Terdapat data jarak, data jalan, data kategori, dan sub kategori.

2. Strukur Tabel

Struktur tabel menggunakan struktur tabel didalam database dimana terdapat data admin, data villa, kategori, data jalan, dan data jarak.

e. Desain Interface

Desain Interface digunakan untuk menggambarkan struktur tampilan website berbasis webgis yang akan diterapkan kedalam aplikasi.

\subsection{Implementasi Sistem}

Implementasi dalam pembuatan aplikasi yaitu menampilkan peta kecamatan tawangmangu yang meliputi jalan persimpangan Kecamtan Tawangmangu, yang ditampilkan menggunakan Google Maps Api, selanjutnya perhitungan mengunakan Algoritma Floyd Warshall.

\subsection{Pengujian Sistem}

1. Blackbox Testing

Pada pengujian fungsional sistem ini menggunakan teknik pengujian Black Box Testing. Pengujian dilakukan melihat apakah hasil masukan sistem benar dengan membandingkan hasil keluaran sistem.

2. Pengujian validitas

Pengujian Validitas dilakuan dengan cara membandingkan perhitungan program dengan perhitungan manual, sehingga dapat diketahui tingkat akurasi program yang kita buat. Pada pengujian validitas hal yang harus dilakukan menghitung secara manual dan perhitungan sistem memiliki persamaan yang akurat.

3. Uji Kelayakan

Pengujian kelayakan pada software pemilihan rute terdekat ini dilakukan dalam cara melakukan kuisioner kepada sekitar 8 orang kemudian hasilnya dihitung apakah memang layak untuk digunakan dan pengujian google maps apakah sama atau berbeda dengan google maps.

\section{HASIL DAN PEMBAHASAN}

Algoritma Floyd Warshall disini membandingkan semua kemungkinan lintasan pada graf untuk setiap sisi dari semua simpulnya. Hal ini dapat terjadi karena adanya perkiraan pengambilan keputusan (pemilihan jalur terpendek) pada setiap tahap antar dua simpul, hingga perkiraan tersebut diketahui sebagai nilai optimal.

Dalam contoh kasus ini diambil 15 titik atau node dengan Pertigaan Pojok (T01) sebagai titik awal dan Villa Indra Sari (T10) sebagai titik tujuan, beserta jarak antar titik dengan satuan meter.

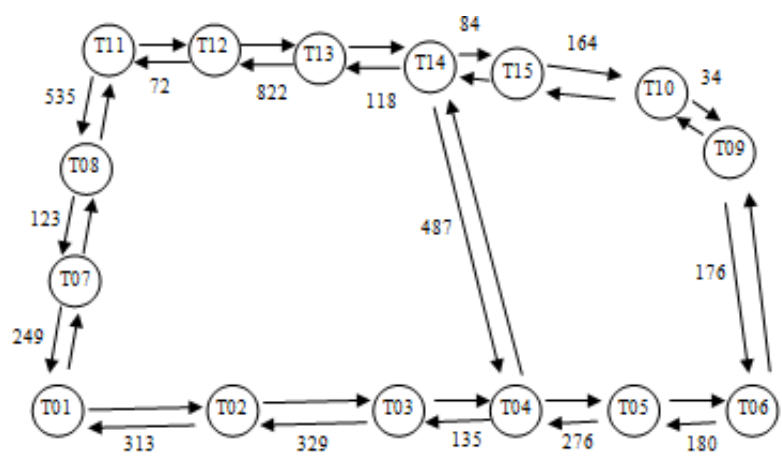

Gambar 2 Contoh kasus Rute Terpendek

Keterangan :

T01 = Pertigaan Pojok

T02 = Pertigaan Smp Amal Mulya

T03 = Perempatan Karangkulon

T04 = Pertigaan Grojokan

T05 = Perempatan Toko Murah

T06 = Perempatan Banjarsari 
T07 = Perempatan Pukesmas

T08 = Perempatan Lilik

T09 = Pertigaan Anggi

T10 = Villa Indra Sari

T11 = Pertigaan River Hill

T12 = Villa Wisma Bayangkara

T13 = Villa Solomia

$\mathrm{T} 14=$ Pertigaan Petasan

$\mathrm{T} 15=$ Pertigaan Pion

Dari Graf yang telah diberikan seperti Gambar 2, yang akan dilewati berdasarkan perhitungan manual yaitu dengan cara menjumlahkan jarak node yang terhubung dari titik awal ke titik tujuan pada setiap node yang dapat dilewati.

- T01-T02-T03-T04-T14-T15-T10 dengan panjang $1512 \mathrm{~m}$
- T01-T07-T08-T11-T12-T13-T14-T15T10 dengan panjang $2167 \mathrm{~m}$

- T01-T02-T03-T04-T05-T06-T09-T10 dengan panjang $1443 \mathrm{~m}$

Diperoleh hasil rute terpendek dari T01 ke T10 yaitu : T01-T02-T03-T04-T05-T06-T09T10 dengan total jarak $1443 \mathrm{~m}$, dimana melewati titik Pertigaan Pojok - Pertigaan Smp Amal Mulya - Pertigaan Karangkulon Pertigaan Grojokan - Perempatan Toko Murah - Perempatan Banjarsari - Pertigaan Anggi Villa Indra Sari

Berdasarkan ilustrasi contoh graf pada Gambar 2, dimodelkan ke dalam algoritma Floyd-Warshall sehingga diperoleh matrik $\mathrm{W}_{0}$ seperti Tabel 2 :

Tabel 2 Matrik $\mathrm{W}_{0}$

\begin{tabular}{|c|c|c|c|c|c|c|c|c|c|c|c|c|c|c|c|}
\hline Dari/ke & T01 & T02 & T03 & T04 & T05 & T06 & T07 & T08 & T09 & T10 & T11 & T12 & T13 & T14 & T15 \\
\hline T01 & 0 & 313 & $\infty$ & $\infty$ & $\infty$ & $\infty$ & 249 & $\infty$ & $\infty$ & $\infty$ & $\infty$ & $\infty$ & $\infty$ & $\infty$ & $\infty$ \\
\hline T02 & 313 & 0 & 329 & $\infty$ & $\infty$ & $\infty$ & $\infty$ & $\infty$ & $\infty$ & $\infty$ & $\infty$ & $\infty$ & $\infty$ & $\infty$ & $\infty$ \\
\hline T03 & $\infty$ & 329 & 0 & 135 & $\infty$ & $\infty$ & $\infty$ & $\infty$ & $\infty$ & $\infty$ & $\infty$ & $\infty$ & $\infty$ & $\infty$ & $\infty$ \\
\hline T04 & $\infty$ & $\infty$ & 135 & 0 & 276 & $\infty$ & $\infty$ & $\infty$ & $\infty$ & $\infty$ & $\infty$ & $\infty$ & $\infty$ & 487 & $\infty$ \\
\hline T05 & $\infty$ & $\infty$ & $\infty$ & 276 & 0 & 180 & $\infty$ & $\infty$ & $\infty$ & $\infty$ & $\infty$ & $\infty$ & $\infty$ & $\infty$ & $\infty$ \\
\hline T06 & $\infty$ & $\infty$ & $\infty$ & $\infty$ & 180 & 0 & $\infty$ & $\infty$ & 176 & $\infty$ & $\infty$ & $\infty$ & $\infty$ & $\infty$ & $\infty$ \\
\hline T07 & 249 & $\infty$ & $\infty$ & $\infty$ & $\infty$ & $\infty$ & 0 & 123 & $\infty$ & $\infty$ & $\infty$ & $\infty$ & $\infty$ & $\infty$ & $\infty$ \\
\hline T08 & $\infty$ & $\infty$ & $\infty$ & $\infty$ & $\infty$ & $\infty$ & 123 & 0 & $\infty$ & $\infty$ & 535 & $\infty$ & $\infty$ & $\infty$ & $\infty$ \\
\hline T09 & $\infty$ & $\infty$ & $\infty$ & $\infty$ & $\infty$ & 176 & $\infty$ & $\infty$ & 0 & 34 & $\infty$ & $\infty$ & $\infty$ & $\infty$ & $\infty$ \\
\hline T10 & $\infty$ & $\infty$ & $\infty$ & $\infty$ & $\infty$ & $\infty$ & $\infty$ & $\infty$ & 34 & 0 & $\infty$ & $\infty$ & $\infty$ & $\infty$ & 164 \\
\hline T11 & $\infty$ & $\infty$ & $\infty$ & $\infty$ & $\infty$ & $\infty$ & $\infty$ & 535 & $\infty$ & $\infty$ & 0 & 72 & $\infty$ & $\infty$ & $\infty$ \\
\hline T12 & $\infty$ & $\infty$ & $\infty$ & $\infty$ & $\infty$ & $\infty$ & $\infty$ & $\infty$ & $\infty$ & $\infty$ & 72 & 0 & 822 & $\infty$ & $\infty$ \\
\hline T13 & $\infty$ & $\infty$ & $\infty$ & $\infty$ & $\infty$ & $\infty$ & $\infty$ & $\infty$ & $\infty$ & $\infty$ & $\infty$ & 822 & 0 & 118 & $\infty$ \\
\hline T14 & $\infty$ & $\infty$ & $\infty$ & 487 & $\infty$ & $\infty$ & $\infty$ & $\infty$ & $\infty$ & $\infty$ & $\infty$ & $\infty$ & 118 & 0 & 84 \\
\hline T15 & $\infty$ & $\infty$ & $\infty$ & $\infty$ & $\infty$ & $\infty$ & $\infty$ & $\infty$ & $\infty$ & 164 & $\infty$ & $\infty$ & $\infty$ & 84 & 0 \\
\hline
\end{tabular}

Langkah selanjutnya melakukan perhitungann dengan rumus $\mathrm{W}[\mathrm{i}, \mathrm{j}]=\min$ $(\mathrm{W}[i, j], W[i, k]+W[k, j])$. Dengan dimulai dari iterasi $\mathrm{K}=\mathrm{T} 01$ sampai $\mathrm{K}=\mathrm{T} 15$ berdasarkan Tabel 1.

1. Iterasi $\mathrm{K}=\mathrm{T} 01$

a. Untuk $\mathrm{i}=\mathrm{T} 01, \mathrm{j}=\{\mathrm{T} 01, \mathrm{~T} 02, \mathrm{~T} 03, \mathrm{~T} 04$, T05,T06,T07,T08,T09,T10,T11,T12,T13,T1 $4, \mathrm{~T} 15\}$

- $\mathrm{W}[\mathrm{T} 01, \mathrm{~T} 01]=\min (0,0+0)=0$

- $\mathrm{W}[\mathrm{T01}, \mathrm{T02}]=\min (313,0+313)=313$

- $\mathrm{W}[\mathrm{T} 01, \mathrm{T03}]=\min (\infty, 0+\infty)=\infty$

- $\mathrm{W}[\mathrm{T} 01, \mathrm{~T} 04]=\min (\infty, 0+\infty)=\infty$

- $\mathrm{W}[\mathrm{T} 01, \mathrm{~T} 05]=\min (\infty, 0+\infty)=\infty$

- $\mathrm{W}[\mathrm{T} 01, \mathrm{~T} 06]=\min (\infty, 0+\infty)=\infty$

- $\mathrm{W}[\mathrm{T01}, \mathrm{T07}]=\min (249,0+249)=249$

- $\mathrm{W}[\mathrm{T} 01, \mathrm{~T} 08]=\min (\infty, 0+\infty)=\infty$

- $\mathrm{W}[\mathrm{T} 01, \mathrm{~T} 09]=\min (\infty, 0+\infty)=\infty$
- $\mathrm{W}[\mathrm{T} 01, \mathrm{~T} 10]=\min (\infty, 0+\infty)=\infty$

- $\mathrm{W}[\mathrm{T} 01, \mathrm{~T} 11]=\min (\infty, 0+\infty)=\infty$

- $\mathrm{W}[\mathrm{T} 01, \mathrm{~T} 12]=\min (\infty, 0+\infty)=\infty$

- $\mathrm{W}[\mathrm{T} 01, \mathrm{~T} 13]=\min (\infty, 0+\infty)=\infty$

- $\mathrm{W}[\mathrm{T} 01, \mathrm{~T} 14]=\min (\infty, 0+\infty)=\infty$

- $\mathrm{W}[\mathrm{T} 01, \mathrm{~T} 15]=\min (\infty, 0+\infty)=\infty$

b. Untuk $\mathrm{i}=\mathrm{T} 02, \mathrm{j}=\{\mathrm{T} 01, \mathrm{~T} 02, \mathrm{~T} 03, \mathrm{~T} 04$, T05,T06,T07,T08,T09,T10,T11,T12,T13,T1 $4, \mathrm{~T} 15\}$

- $\mathrm{W}[\mathrm{T02}, \mathrm{T01}]=\min (\infty, 313+0)=313$

- $\mathrm{W}[\mathrm{T02}, \mathrm{T02}]=\min (0,313+313)=0$

- $\mathrm{W}[\mathrm{T02}, \mathrm{T03}]=\min (329,313+\infty)=329$

- $\mathrm{W}[\mathrm{T} 02, \mathrm{~T} 04]=\min (\infty, 313+\infty)=\infty$

- $\mathrm{W}[\mathrm{T} 02, \mathrm{~T} 05]=\min (\infty, 313+\infty)=\infty$

- $\mathrm{W}[\mathrm{T} 02, \mathrm{~T} 06]=\min (\infty, 313+\infty)=\infty$

- $\mathrm{W}[\mathrm{T} 02, \mathrm{~T} 07]=\min (\infty, 313+249)=562$

- $\mathrm{W}[\mathrm{T} 02, \mathrm{~T} 08]=\min (\infty, 313+\infty)=\infty$ 
- $\mathrm{W}[\mathrm{T} 02, \mathrm{~T} 09]=\min (\infty, 313+\infty)=\infty$

- $\mathrm{W}[\mathrm{T} 02, \mathrm{~T} 10]=\min (\infty, 313+\infty)=\infty$

- $\mathrm{W}[\mathrm{T} 02, \mathrm{~T} 11]=\min (\infty, 313+\infty)=\infty$

- $\mathrm{W}[\mathrm{T} 02, \mathrm{~T} 12]=\min (\infty, 313+\infty)=\infty$

- $\mathrm{W}[\mathrm{T} 02, \mathrm{~T} 13]=\min (\infty, 313+\infty)=\infty$

- $\mathrm{W}[\mathrm{T} 02, \mathrm{~T} 14]=\min (\infty, 313+\infty)=\infty$

- $\mathrm{W}[\mathrm{T} 02, \mathrm{~T} 15]=\min (\infty, 313+\infty)=\infty$

c. Untuk $\mathrm{i}=\mathrm{T} 03, \mathrm{j}=\{\mathrm{T} 01, \mathrm{~T} 02, \mathrm{~T} 03, \mathrm{~T} 04$ T05,T06,T07,T08,T09,T10,T11,T12,T13,T1 $4, \mathrm{~T} 15\}$

- $\mathrm{W}[\mathrm{T} 03, \mathrm{T01}]=\min (\infty, \infty+0)=\infty$

- $\mathrm{W}[\mathrm{T03}, \mathrm{T02}]=\min (329, \infty+313)=329$

- $\mathrm{W}[\mathrm{T} 03, \mathrm{~T} 03]=\min (0, \infty+\infty)=0$

- $\mathrm{W}[\mathrm{T} 03, \mathrm{~T} 04]=\min (135, \infty+\infty)=135$

- $\mathrm{W}[\mathrm{T} 03, \mathrm{T05}]=\min (\infty, \infty+\infty)=\infty$

- $\mathrm{W}[\mathrm{T} 03, \mathrm{~T} 06]=\min (\infty, \infty+\infty)=\infty$

- $\mathrm{W}[\mathrm{T} 03, \mathrm{T07}]=\min (\infty, \infty+249)=\infty$
- $\mathrm{W}[\mathrm{T} 03, \mathrm{~T} 08]=\min (\infty, \infty+\infty)=\infty$

- $\mathrm{W}[$ T03,T09] $=\min (\infty, \infty+\infty)=\infty$

- $\mathrm{W}[\mathrm{T} 03, \mathrm{~T} 10]=\min (\infty, \infty+\infty)=\infty$

- $\mathrm{W}[$ T03,T11] $=\min (\infty, \infty+\infty)=\infty$

- $\mathrm{W}[\mathrm{T} 03, \mathrm{~T} 12]=\min (\infty, \infty+\infty)=\infty$

- $\mathrm{W}[\mathrm{T} 03, \mathrm{~T} 13]=\min (\infty, \infty+\infty)=\infty$

- $\mathrm{W}[\mathrm{T} 03, \mathrm{~T} 14]=\min (\infty, \infty+\infty)=\infty$

- $\mathrm{W}[\mathrm{T} 03, \mathrm{~T} 15]=\min (\infty, \infty+\infty)=\infty$ $\mathrm{k} 15$,

Perhitungan terus dilakukan sampai $\mathrm{I}=$ $\mathrm{j}=\{\mathrm{T} 01, \mathrm{T02}, \mathrm{T03}, \mathrm{T04}, \mathrm{T05}, \mathrm{T06}, \mathrm{T07}, \mathrm{T08}$, T09,T10,T11,T12,T13,T14,T15\}. Kemudian dilanjutkan sampai ke iterasi $\mathrm{k}=\mathrm{T} 15$, dimana perhitungan sama dengan iterasi $\mathrm{k}=1$. Hasil iterasi $\mathrm{k}=\mathrm{T} 15$ berikut

Tabel 3 Matrik iterasi $\mathrm{K}=1=\mathrm{T} 15$

\begin{tabular}{|l|c|c|c|c|c|c|c|c|c|c|c|c|c|c|c|}
\hline Dari/ke & T01 & T02 & T03 & T04 & T05 & T06 & T07 & T08 & T09 & T10 & T11 & T12 & T13 & T14 & T15 \\
\hline T01 & 0 & 313 & 642 & 777 & 1053 & 1233 & 249 & 372 & 1409 & 1443 & 907 & 979 & 1382 & 1264 & 1348 \\
\hline T02 & 313 & 0 & 329 & 464 & 740 & 920 & 562 & 685 & 1096 & 1130 & 1220 & 1292 & 1069 & 951 & 1035 \\
\hline T03 & 642 & 329 & 0 & 135 & 411 & 591 & 891 & 1014 & 767 & 801 & 1549 & 1562 & 740 & 622 & 706 \\
\hline T04 & 777 & 464 & 135 & 0 & 276 & 456 & 1026 & 1149 & 632 & 666 & 1499 & 1427 & 605 & 487 & 571 \\
\hline T05 & 1053 & 740 & 411 & 276 & 0 & 180 & 1302 & 1425 & 356 & 390 & 1650 & 1578 & 756 & 638 & 554 \\
\hline T06 & 1233 & 920 & 591 & 456 & 180 & 0 & 1482 & 1781 & 176 & 210 & 1470 & 1398 & 576 & 458 & 374 \\
\hline T07 & 249 & 562 & 891 & 1026 & 1302 & 1482 & 0 & 123 & 1658 & 1692 & 658 & 730 & 1552 & 1513 & 1597 \\
\hline T08 & 372 & 685 & 1014 & 1149 & 1425 & 1781 & 123 & 0 & 1781 & 1795 & 535 & 607 & 1429 & 1547 & 1631 \\
\hline T09 & 1409 & 1096 & 767 & 632 & 356 & 176 & 1658 & 1781 & 0 & 34 & 1294 & 1222 & 400 & 282 & 198 \\
\hline T10 & 1443 & 1130 & 801 & 666 & 390 & 210 & 1692 & 1795 & 34 & 0 & 1260 & 1188 & 366 & 248 & 164 \\
\hline T11 & 907 & 1220 & 1549 & 1499 & 1650 & 1470 & 658 & 535 & 1294 & 1260 & 0 & 72 & 894 & 1012 & 1096 \\
\hline T12 & 979 & 1292 & 1562 & 1427 & 1578 & 1398 & 730 & 607 & 1222 & 1188 & 72 & 0 & 822 & 940 & 1024 \\
\hline T13 & 1382 & 1069 & 740 & 605 & 756 & 576 & 1552 & 1429 & 400 & 366 & 892 & 822 & 0 & 118 & 202 \\
\hline T14 & 1264 & 951 & 622 & 487 & 638 & 458 & 1513 & 1547 & 282 & 248 & 1012 & 940 & 118 & 0 & 84 \\
\hline T15 & 1348 & 1035 & 706 & 571 & 554 & 374 & 1597 & 1631 & 198 & 164 & 1096 & 1024 & 202 & 84 & 0 \\
\hline
\end{tabular}

Berdasarkan matrik pada Tabel 3 akan dicari rute terpendek dari T01 ke T10 berdasarkan perhitungan algoritma Floyd Warshall adalah T01 - T02 - T03 - T04 - T05 - T06 - T09 - T10 dengan jarak 1443 meter.

Perancangan sistem dilakukan menggunakan Diagram Konteks, HIPO, DFD dan menggunakan interface Bootstrap serta XAMPP Web Server.

Diagram konteks secara garis besar menggambarkan sistem penentuan rute terpendek dengan memperlihantkan masukkan, proses, dan keluaran dari sistem yang akan dirancang untuk penentuan rute terpendek lokasi villa di Kecamatan Tawangmangu. Adapun Diagram Konteks dapat ditunjukkan pada Gambar 3.

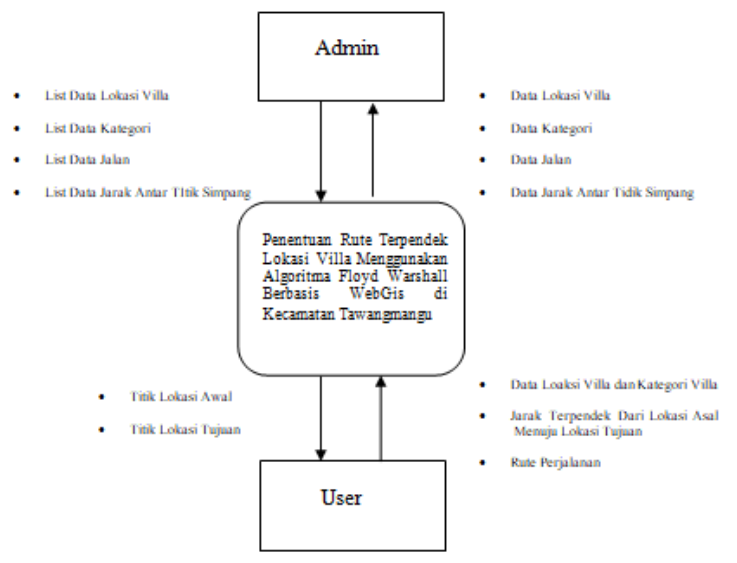

\section{Gambar 3 Diagram Konteks}

Hierarcy Input Process Output (HIPO) digunakan untuk teknik pendokumentasian program yang dapat digunakan untuk mengkomunikasikan spesifikasi sistem kepada para level-level lebih bawah lagi. Setiap modul 
HIPO digambarkan oleh fungsi utamanya. Diagram HIPO dapat ditunjukkan pada Gambar 4.

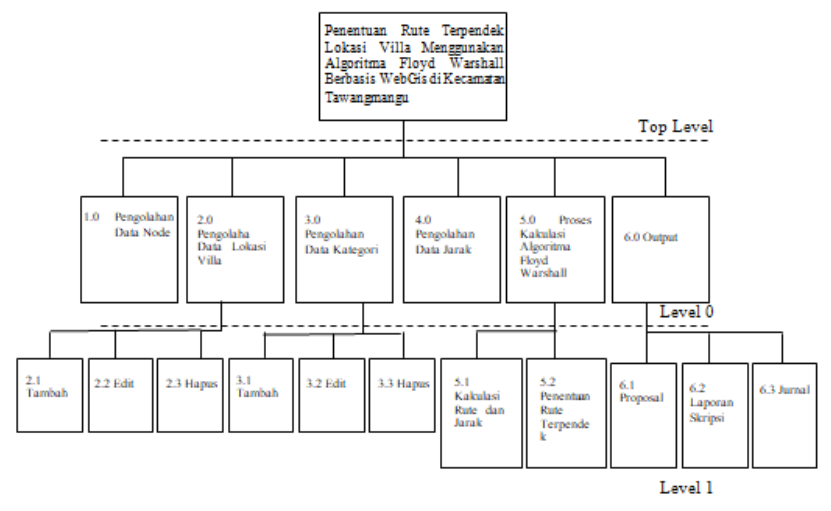

Gambar 4 Diagram HIPO

Data Flow Diagram atau DFD merupakan diagram diagram aliran data dimana menjelaskan masing-masing bagian dan fungsinya dalam menerima dan mengirim data. Data Flow Diagram dapat ditunjukkan pada Gambar 5.

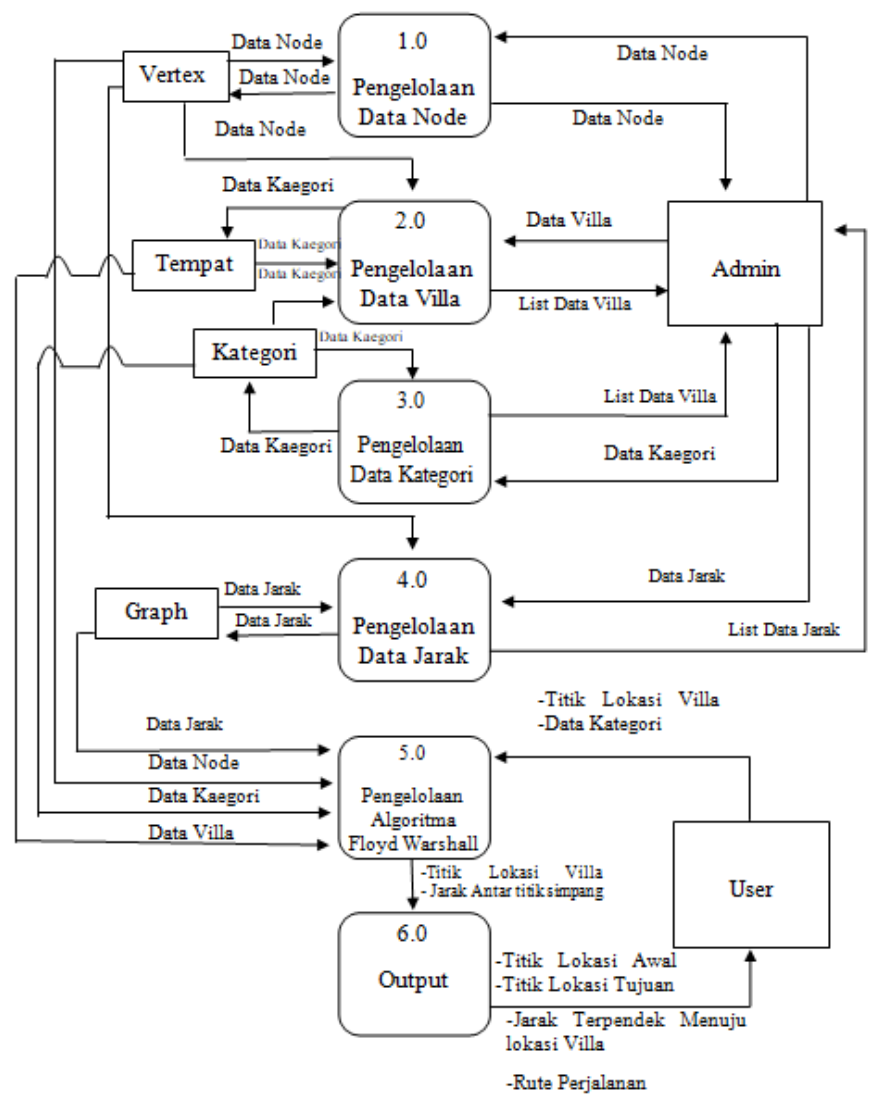

\section{Gambar 5 Data Flow Diagram}

Entity Relationship Diagram

(ERD) digunakan untuk menggambarkan keterkaitan data antar field dan tabel di dalam database. Database yang digunakan adalah database
MySQL. Adapun diagram ERD dapat ditunjukkan pada Gambar 6

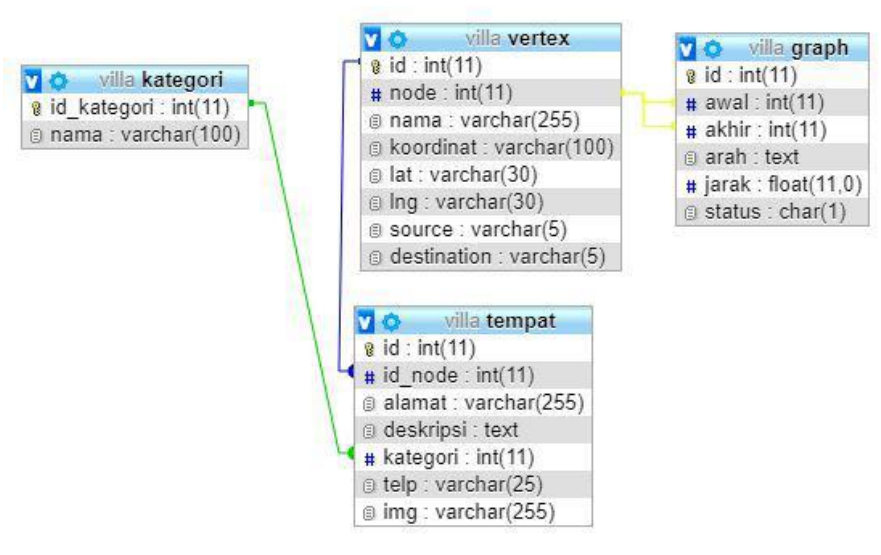

\section{Gambar 6 ERD Database}

Interface web digunakan untuk memudahkan pengelolaan dan menampilkan hasil ke dalam bentuk tampilan yang mudah dipahami serta dapat digunakan oleh user umum. Interface web dapat ditunjukkan pada Gambar 7.

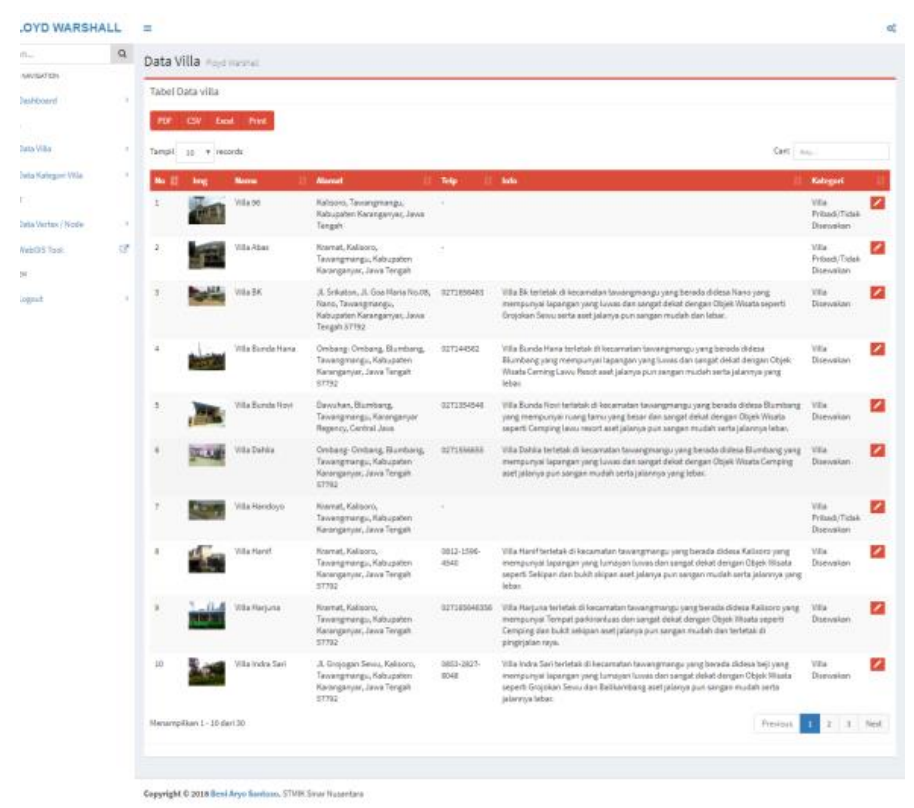

\section{Gambar 7 Interface Web}

Dalam pengujian yang dapat diuraikan pada Tabel 4 yang telah dilakukan dan hasil perhitungan manual dan perhitungan program pada Gambar 8 adalah sama.

\section{Tabel 4. Pengujian}

\begin{tabular}{|c|c|c|c|c|c|}
\hline \multirow{3}{*}{ Rute } & \multicolumn{2}{|c|}{ Manual } & \multicolumn{2}{c|}{ Program } & Hasil \\
\cline { 2 - 6 } & Rute Alternatif & Jarak & Rute & Jarak & \\
\hline \multirow{2}{*}{} & $\begin{array}{c}\text { T01-T02-T03- } \\
\text { T04-T14-T15- }\end{array}$ & 1512 & & 1443 & $\begin{array}{c}\text { Hasil } \\
\text { Sama }\end{array}$ \\
\hline
\end{tabular}




\begin{tabular}{|c|c|c|c|c|c|}
\hline \multirow{2}{*}{ Rute } & \multicolumn{2}{|c|}{ Manual } & \multicolumn{2}{|c|}{ Program } & \\
\hline & Rute Alternatif & Jarak & Rute & Jarak & \\
\hline \multirow{5}{*}{$\begin{array}{l}\text { T01 - } \\
\text { T10 }\end{array}$} & $\mathrm{T} 10$ & & \multirow{5}{*}{$\begin{array}{l}\frac{T 01-}{T 02-} \\
\frac{T 03-}{T} \\
\frac{T 04-}{T 05-} \\
\frac{T 06-}{T 09-} \\
\frac{T 10}{T 10}\end{array}$} & & \\
\hline & T01-T02-T03- & & & & \\
\hline & T04-T05-T06- & 1443 & & & \\
\hline & $\frac{\text { T09-T10 }}{\text { T01-T07-T08- }}$ & & & & \\
\hline & $\begin{array}{l}\text { T11-T12-T13- } \\
\text { T14-T15-T10 }\end{array}$ & 2167 & & & \\
\hline
\end{tabular}

Penghitungan manual ini merupakan penghitungan yang dilakukan secara offline. Dimana diukur dilapangan dengan menggunakan kendaraan bermotor. Sedangkan penghitungan program, berdasarkan jumlah jarak antar titik yang dilalui mulai dari awal sampai tujuan. Jarak diambil berdasarkan koordinat di masing-masing titik.

\section{Gambar 8 Hasil perhitungan program}

Pengujian kelayakan digunakan untuk mengukur tingkat kelayakan penggunaan aplikasi untuk dioperasikan. Pengujian ini dilakukan dengan cara membandingkan dengan Google Maps yang sudah di lakukan.

Tabel 5 pengujian dengan Google Maps

\begin{tabular}{|c|c|c|}
\hline Lokasi Asal & $\begin{array}{c}\text { Lokasi } \\
\text { Tujuan }\end{array}$ & $\begin{array}{c}\text { Perbandingan } \\
\text { Program Dengan } \\
\text { Google Map }\end{array}$ \\
\hline $\begin{array}{c}\text { Perempatan } \\
\text { Balekambang }\end{array}$ & Villa Subasa & $\begin{array}{c}\text { Berbeda Dengan } \\
\text { Program }\end{array}$ \\
\hline Villa Tanaman & Villa & $\begin{array}{c}\text { Berbeda Dengan } \\
\text { Protogram }\end{array}$ \\
\hline Perempatan & Villa & Berbeda Dengan \\
Banjarsari & Stroberry & Program \\
\hline Pertigaan Smp & Villa & Berbeda Dengan \\
Amal Mulya & Bayangkara & Program \\
\hline Villa Stroberry & Villa Indra & Berbeda Dengan \\
& Sari & Program \\
\hline \hline
\end{tabular}

\begin{tabular}{|c|c|c|}
\hline Lokasi Asal & $\begin{array}{l}\text { Lokasi } \\
\text { Tujuan }\end{array}$ & $\begin{array}{l}\text { Perbandingan } \\
\text { Program Dengan } \\
\text { Google Map }\end{array}$ \\
\hline $\begin{array}{c}\text { Perempatan Bu } \\
\text { Ugi }\end{array}$ & Villa Solomia & $\begin{array}{c}\text { Berbeda Dengan } \\
\text { Program }\end{array}$ \\
\hline $\begin{array}{c}\text { Perempatan } \\
\text { Londo }\end{array}$ & Villa Sar & $\begin{array}{c}\text { Berbeda Dengan } \\
\text { Program }\end{array}$ \\
\hline $\begin{array}{l}\text { Perempatan } \\
\text { Bener }\end{array}$ & Villa 96 & $\begin{array}{c}\text { Berbeda Dengan } \\
\text { Program }\end{array}$ \\
\hline Grojokan & $\begin{array}{l}\text { Villa Panti } \\
\text { Asri }\end{array}$ & $\begin{array}{c}\text { Berbeda Dengan } \\
\text { Program }\end{array}$ \\
\hline Pertigaan Pion & Villa BK & $\begin{array}{c}\text { Berbeda Dengan } \\
\text { Program }\end{array}$ \\
\hline $\begin{array}{l}\text { Pertigaan } \\
\text { Petasan }\end{array}$ & $\begin{array}{c}\text { Villa Murnia } \\
\text { Husein }\end{array}$ & $\begin{array}{c}\text { Berbeda Dengan } \\
\text { Program }\end{array}$ \\
\hline $\begin{array}{c}\text { Perempatan } \\
\text { Pukesmas }\end{array}$ & $\begin{array}{c}\text { Villa } \\
\text { Masikama }\end{array}$ & $\begin{array}{c}\text { Berbeda Dengan } \\
\text { Program }\end{array}$ \\
\hline Pertigaan Pojok & $\begin{array}{l}\text { Villa Sari } \\
\text { Asih }\end{array}$ & $\begin{array}{c}\text { Berbeda Dengan } \\
\text { Program }\end{array}$ \\
\hline $\begin{array}{l}\text { Pertigaan } \\
\text { Jembatan }\end{array}$ & Villa Harjuna & $\begin{array}{c}\text { Berbeda Dengan } \\
\text { Program }\end{array}$ \\
\hline Pertigaan Naga & $\begin{array}{c}\text { Villa } \\
\text { Tanaman }\end{array}$ & $\begin{array}{c}\text { Berbeda Dengan } \\
\text { Program }\end{array}$ \\
\hline Grojokan Sewu & Villa Hanif & $\begin{array}{c}\text { Berbeda Dengan } \\
\text { Program }\end{array}$ \\
\hline Perempatan Wc & Villa Abas & $\begin{array}{c}\text { Berbeda Dengan } \\
\text { Program }\end{array}$ \\
\hline $\begin{array}{c}\text { Perempatan } \\
\text { Kampung baru }\end{array}$ & Villa Marais & $\begin{array}{c}\text { Berbeda Dengan } \\
\text { Program }\end{array}$ \\
\hline Pertigaan Anggi & Villa Maya & $\begin{array}{c}\text { Berbeda Dengan } \\
\text { Program }\end{array}$ \\
\hline $\begin{array}{l}\text { Perempatan } \\
\text { Sari }\end{array}$ & Villa Sritek & $\begin{array}{l}\text { Berbeda Dengan } \\
\text { Program }\end{array}$ \\
\hline $\begin{array}{c}\text { Pwertigaan } \\
\text { River Hill }\end{array}$ & Villa Dahlia & $\begin{array}{c}\text { Berbeda Dengan } \\
\text { Program }\end{array}$ \\
\hline $\begin{array}{l}\text { Pertigaan } \\
\text { Butransno }\end{array}$ & $\begin{array}{c}\text { Villa Bunda } \\
\text { Hana }\end{array}$ & $\begin{array}{c}\text { Berbeda Dengan } \\
\text { Program }\end{array}$ \\
\hline Perempatan lilik & Villa Putih & $\begin{array}{c}\text { Berbeda Dengan } \\
\text { Program }\end{array}$ \\
\hline $\begin{array}{l}\text { Pertigaan } \\
\text { Pancot }\end{array}$ & $\begin{array}{c}\text { Villa Bunda } \\
\text { Novi }\end{array}$ & $\begin{array}{c}\text { Berbeda Dengan } \\
\text { Program }\end{array}$ \\
\hline $\begin{array}{l}\text { Pertigaan Oro- } \\
\text { oro }\end{array}$ & Villa Je & $\begin{array}{c}\text { Sama Dengan } \\
\text { Program }\end{array}$ \\
\hline $\begin{array}{c}\text { Perempatan } \\
\text { Matisih }\end{array}$ & $\begin{array}{c}\text { Villa } \\
\text { Handoyo }\end{array}$ & $\begin{array}{c}\text { Sama Dengan } \\
\text { Program }\end{array}$ \\
\hline $\begin{array}{c}\text { Pasar } \\
\text { Tawangmangu }\end{array}$ & Villa Vtec & $\begin{array}{c}\text { Sama Dengan } \\
\text { Program }\end{array}$ \\
\hline Pertigaan $\mathrm{Hi}$ & Villa Titi Sari & $\begin{array}{c}\text { Sama Dengan } \\
\text { Program }\end{array}$ \\
\hline $\begin{array}{c}\text { Pertigaan } \\
\text { Sakaw }\end{array}$ & Villa Sartika & $\begin{array}{c}\text { Sama Dengan } \\
\text { Program }\end{array}$ \\
\hline $\begin{array}{l}\text { Pertigaan } \\
\text { Sekipan }\end{array}$ & $\begin{array}{c}\text { Villa Wahyu } \\
\text { Kinanti }\end{array}$ & $\begin{array}{c}\text { Sama Dengan } \\
\text { Program }\end{array}$ \\
\hline
\end{tabular}

Berdasarkan percobaan pengujian kelayakan menggunakan Google Maps pada Tabel 5 menunjukan hasil yang berbeda mendapatkan persentase perbedaan $80 \%$ dari 30 jalur percobaan dengan Google Maps.

Perbedaan ini dikarenakan Google Maps membaca kondisi lalu lintas jalan, dan membandingkan referensi jalan lain. Selain itu, penggunaan Floyd-Warshall ini hanya mengacu pada jalan yang dapat dilalui dengan kendaraan roda 2 atau lebih. 
Pengujian kelayakan juga dilakukan untuk mengukur kepuasan pengguna aplikasi. Mulai dari kemudahan menggunakan aplikasi, lokasi mudah digunakan untuk menetukan titik awal dan tujuan, memudahkan pencarian Villa sampai dengan tampilan interface yang menarik.

Dari 8 (delapan) responden yang diambil secara acak, menunjukkan persentase kelayakan sebesar 88,75\% diukur dengan skala linkert 5 (lima) untuk masing-masing lima pernyataan.

\section{PENUTUP}

Berdasarkan dari analisa dan implementasi sistem penentuan rute terpendek lokasi villa di Kecamatan Tawangmangu yang dilakukan, maka dapat diambil beberapa kesimpulan yaitu dapat memudahkan pengguna untuk menentukan lokasi villa dan rute terpendek yang menggunakan perhitungan Floyd warshall dari lokasi asal sampai lokasi tujuan villa dan informasi berkaitan dengan villa lebih rinci.

Pengujian kelayakan dengan responden menunjukan hasil persentasi kelayakan sebesar $88,75 \%$ yang menunjukkan bahwa aplikasi yang dibuat sangat layak digunakan oleh pengguna, dan Pengujian kelayakan dengan Google Map menunjukan bahwa program dengan Google Maps ada perbedaan $80 \%$ dari pengujian jalur berbeda.

Penelitian lebih lanjut dapat dikembangkan dengan penggabungan algoritma yang lainnya serta dapat diimplementasikan ke dalam aplikasi berbasis Android.

\section{DAFTAR PUSTAKA}

[1] E. Budiyanto, S. Pd, and M. Si, "Sistem Informasi Geografis dengan Quantum GIS," Andi, Yogyakarta, 2016.

[2] D. Nugroho and E. Purwanto, "Marker Berbeda-Beda untuk Sistem Informasi Geografis Menggunakan PHP, Google Map API dan Akses Langsung Ke MySql," DutaCom J., vol. 13, no. 1, pp. 71-82, 2017.

[3] W. O. A. P. Wulandari, B. Pramono, and L. M. Tajidun, "Aplikasi Pencarian Rute Terpendek Apotek Di Kota Kendari Menggunakan Algoritma FloydWarshall," semanTIK, vol. 3, no. 1, 2017.

[4] D. B. Prasetyo, "Sistem Informasi Geografis Berbasis Google Maps API untuk Pemetaan Profil Kriminalitas Tipe Konvensional di Wilayah Hukum
Polresta Yogyakarta," J. Tek. Inform. STMIK AMIKOM Yogyakarta, 2014.

[5] H. Sulastri, H. Mubarok, and A. Heykal, "Sistem Pendukung Keputusan Penentuan Rute Terbaik Menuju Posko Pendakian Gunung Ciremai Menggunakan Algoritma Floyd Warshall Dan Weighted Product," in SNIA (Seminar Nasional Informatika dan Aplikasinya), 2019, vol. 4, pp. B17-22.

[6] F. W. Ningrum, "Penerapan Algoritma Floyd-Warshall dalam Menentukan Rute Terpendek pada Pemodelan Jaringan Pariwisata di Kota Semarang." Universitas Negeri Semarang, 2016.

[7] N. K. D. A. Jayanti, "Penggunaan Algoritma Floyd Warshall Dalam Masalah Jalur Terpendek Pada Penentuan Tata Letak Parkir," in Seminar Nasional Informatika (SNIf), 2017, vol. 1, no. 1, pp. 75-81.

[8] J. Kepner and J. Gilbert, Graph algorithms in the language of linear algebra. SIAM, 2011. 